\title{
Hva skal vi si til barn om selvmord?
}

Ved M agne Raundalen

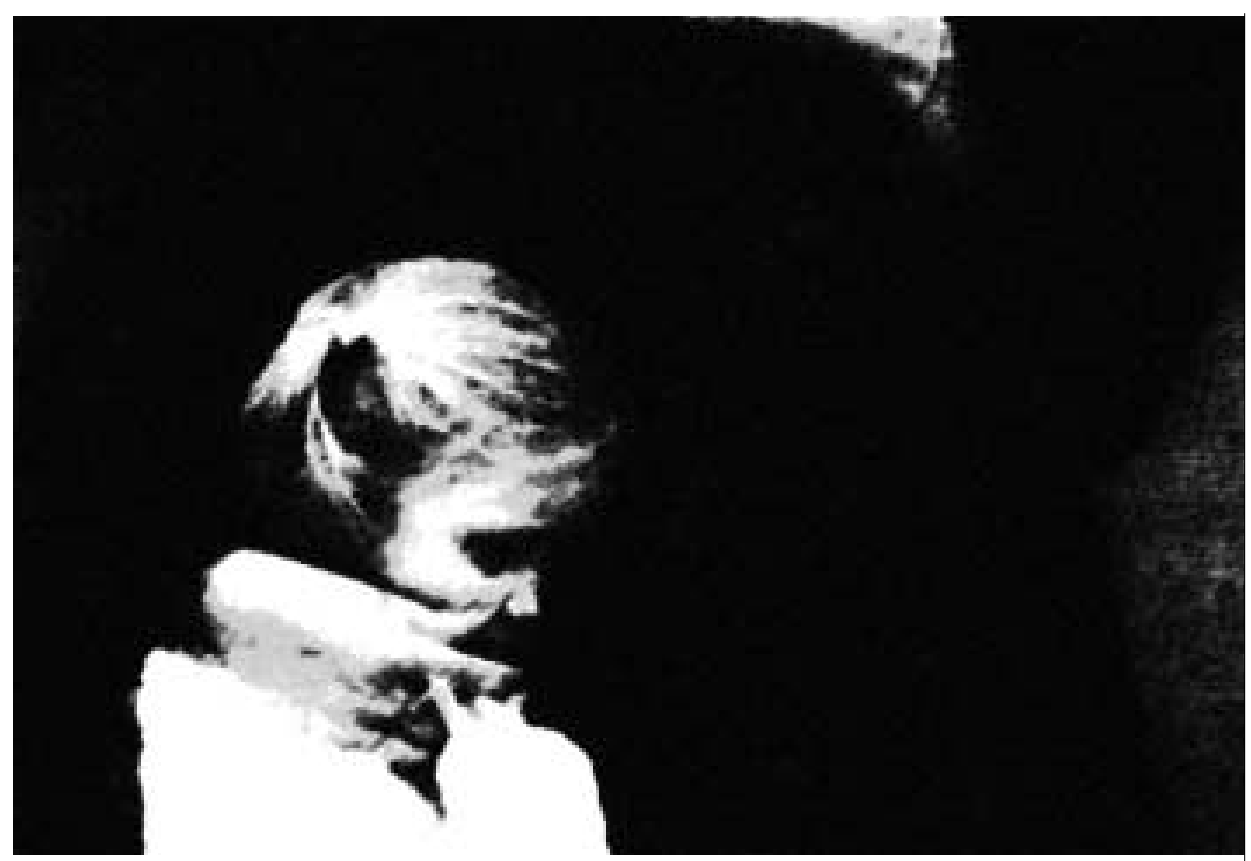

Innledning - eksempler

\section{D atter på seks år}

Etter en forelesning om barn i krise kommer en mor og ber om råd. H un har en datter som nå er seks år. H un forteller at hennes mann, som var datterens pappa, gjorde et planlagt og lenge varslet selvmord for halvannet àr siden; da datteren altså var fire og et halvt år. $\mathrm{H}$ an hadde tatt en overdose, og han ble funnet mens han ennå var i live. $H$ an døde først en uke senere på sykehuset. A kkurat i denne situasjonen syntes moren at hun hadde gjort alt rett. Etter grundige forberedel ser hadde datteren fått se sin far tre ganger på sykehuset. $\mathrm{H}$ un var blitt fortrolig med at han kom til å dø før han døde, og hun hadde deltatt i begravel sen. Det som er morens uro nå er at hun, etter råd fra faglig hold den gang, så bort fra sin egen "magefølelse" og unnlot å fortelle barnet at hennes pappa gjorde det slutt selv. $0 \mathrm{~m}$ dødsårsaken hadde hun kun sagt at hjertet hans hadde sluttet å slå - hvilket jo var "sant". Datteren beskrives nå av mor som en livsfrisk og aktiv skolejente. Skulle hun ha fortalt alt den gang? M itt svar på det var ja - hun skulle ha stolt på sine egne "instinkter". Bør hun fortelle det nå? M itt svar er ja.

\section{B arnebarn på fem}

Samme uke ringer en mormor meg og ber om råd fordi hennes barnebarn på

\section{Selvmord $\mathrm{i}$ barnehagen}

En barn ehagestyrer ringer og beretter at en homofil, mannlig førskolelærer på avdelingen for de største barna, de mellom fire og seks år, har hengt seg i sitt hjem. H un har nettopp fått vite dette av førskolelærerens foreldre, som blant annet forteller at det kommer til å gå fram av dødsannonsen at "livet ble for tungt å bære"; dette for å unngå alle former for rykteskaping og fordi, som de selv uttrykte det: "Tiden er inne for åpenhet om selvmord". Styreren har klart for seg at hun skal innkalle til forel dremøte. Det hun vil spørre meg om er følgende: Skal vi fortelle til barna at det var selvmord? Svaret mitt er ja. Vedkommer det barna at han i sitt avskjedsbrev angir sin homofile legning som årsak til depresjon og selvmordet? Jeg svarer at den avgjørelsen må hun overlate til foreldrene å ta, men jeg gir henne det råd at de forbereder seg på spørsmål fra enkelte foreldre som vil være forberedt på å bringe homofilitemaet på bane.

\section{A penhet om selvmord}

Som eksemplene ovenfor viser, har et langvarig arbeid for større åpenhet om selvmord nådd overflaten. Såvel modige pårøren de som journalister og fagfolk kan dele fortjenesten for det som jeg absolutt ser som et viktig steg framover. Et steg som innebærer at barn kan få klar melding i en krisesituasjon i stedet for å leve i en tåkeheim av fortiel ser, omskrivninger og angstskapen de uvitenhet.

\section{$\mathrm{N}$ y organisasjon for pårørende}

Stiftelsen av en ny organisasjon for pårørende etter selvmord er et sterkt og viktig signal om at mange etterlatte ikke vil leve alene med sorg og selvbebreidelser når noen i deres nære nettverk har tatt sitt eget liv. D enne åpenheten kommer ikke overraskende på oss. Det er allerede gått 15 år siden Solveig Bøhle laget sine skjellsettende radioprogram med pårørende i N RK. Senere ful gte hun dem opp med den sobre og velskrevne boken "N oen blir tilbake". For mer enn ti år siden kom tv-programmene hennes som rystet Det Tause N orge. 


\section{Er vi forberedt på åpenhet til barn?}

Dette til tross, er vi likevel ikke skikkelig forberedt på hvordan vi skal praktisere åpenhet når barn blir tilbake etter selvmord i familien. G jennom årene, når jeg har gitt råd om full åpenhet overfor barna, har jeg jevnlig møtt den samme motstanden. Først kommer påstandene om at vi skal vente til barna spør. Dernest at det ikke går an å lage en oppskrift på hvordan vi skal gjøre det, det får komme naturlig hvis det er naturlig. M eget ofte fikk jeg også høre at de ville vente til barna ble store nok til å forstå det som hadde hendt. $\mathrm{N}$ oen av disse barna ble over 30 år før de våget å begynne å finne ut av det som hadde hendt på egen hånd. $\mathrm{N}$ oen sa det som det var: Jeg klarer det ikke selv, jeg vet ikke hva jeg skal si og hvordan jeg skal få sagt det.

Den første motstanden kunne ofte reduseres ved en dialog om faren for at "vente-til-de-spør"-strategien oppfattes som et klart signal om at de ikke skal spørre. $N$ år det gjaldt innvendingen om at man ikke kunne lage en oppskrift, kunne jeg delvis slutte meg til den påstanden. $H$ vert enkelt barn og hvert enkelt selvmord hadde sin egen, unike historie. Deretter ledet jeg samtalen over på hvordan vi i alle andre sammenhenger drar nytte av andres erfaringer i van skelige spørsmål som gjelder barn. Svært mange begynte å utforme sin egen tilnærming bare ved å lytte til et par eksempler på hvordan det kunne gjøres. En far sa følgende helt spontant: "Før vi snakket sammen, forekom det meg helt umulig å fortelle en 6 åring hvorfor og hvordan hennes storebror (15) tok livet sitt. $N$ å kan jeg nesten ikke vente. $\mathrm{N}$ å forstår jeg at mye av det som har plaget henne, skyldes all uklarheten og våre febrilske forsøk på å avlede og omgå hennes spørsmål."

\section{Hva skal vi si til barna?}

H va skal vi si til de små barna om at noen ikke orker å leve lenger? H vorfor skal vi si noe til dem om selvmord i det hele tatt? Er det ikke nok at de har mistet en av sine nærmeste om de ikke skal bære på en ekstrabyrde av medliden het og kanskje skyldfølelse? $0 \mathrm{~m}$ vi nå forteller de små barna at noen ikke orket å bære det tunge livet, skal de i tillegg være med på bære vår voksne skyld for utstøtingen av de homofile - går det ingen grenser?

\section{Vi må si sannheten}

Det vi sier til barna må være sant. Viktigst med sannheten er at de ikke gradvis opplever at fakta blir verre og verre etter som tiden (årene) går og versjonen av det som skjedde utvides. De må få vite at det var hengning og hva hengning er.

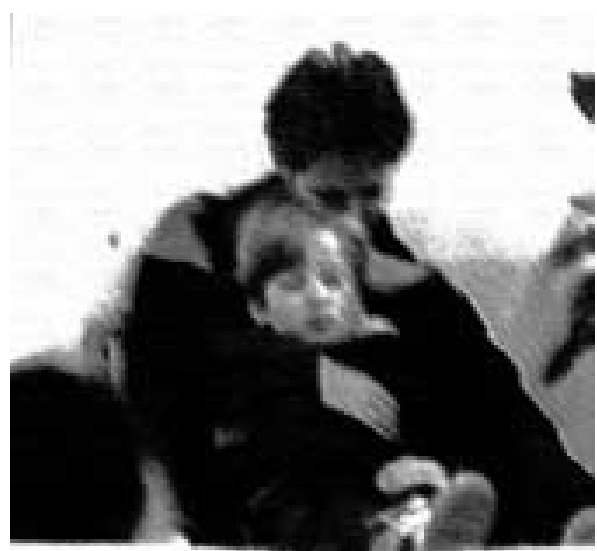

De må få vite om drukning, overdose, skyting og overskårne pul sårer. H vorfor må de få vite det nå? En sentral begrunnelse er den negative virkningen av hemmeligheter i familien. M ed slike hemmeligheter i familien blir mange hendelser og reaksjoner uforståelige for barna. H vorfor gikk pappa ut når jeg begynte å snakke om det, hvorfor ble mamma nesten sint når jeg spurte, hvorfor begynte de å snakke om noe helt annet? $N$ àr barna ikke kan være med i noen form for kommunikasjon om det alle tenker på, får de likevel vite noe, og de opplever at mange arenaer for samtale, spørsmål og kommunikasjon er fulle av snubletråder som er usynlige og angstskapende. I tillegg, når de en gang får vite, er det oppstått en troverdighetskløft fylt av angst og spenning mellom dem og de voksne. N år de kunne bære på slike forferdel ige hemmeligheter over så lang tid uten å fortelle meg om dem, hva bærer de på av andre ubehagelige sjokkmeldinger nå? $0 \mathrm{~g}$ egentlig er det ikke bare en brist $\mathrm{i}$ tilliten til voksne som blir følgen av tausheten. Barna blir regel rett satt utenfor i sin egen familie. Det blir opprettet en glassvegg mellom enkeltbarn, fordi de er så små, og resten av familien. Derfor kan en nesten si som en regel at jo kortere tid det går mellom de forferdelige hendel sene og informasjonene til barna, desto bedre. Jo dårligere forberedt, desto verre.

\section{D epresjon - tankesykdommer}

I de tre første eksemplene var det helt åpenbart at de personene som hadde tatt sitt eget liv, ikke var friske. Jeg sier ikke at de var syke. Til de små barna sier jeg at de hadde tankesykdommer. Jeg har blyant og papir og jeg begynner å tegne tankene som friske, grønne, lange og loddrette streker; noen ganger med blomster på. Disse frodige, grønne og friske tankene er inne i hodet, i hjernen. H jernen trenger lys og varme for at tankene skal holde seg friske. $\mathrm{N}$ år man får en tankesykdom som heter depresjon, blir det mørkt og kaldt der inne hvor tankene skal vokse og gro. Da begynner de å visne. $M$ en det er noen tanker som ikke har visnet helt. De tenker: "Jeg må få hjelp, jeg må snakke med noen som kan hjelpe meg med tankesykdommene, jeg må få medisin". M en dersom de ikke făr hjelp, blir det veldig kaldt og mørkt inne hos tankene, snart visner også tanken om å gå til noen og få hjelp.

\section{A ller sist visner tanken på barna}

$M$ ens jeg snakker om dette, bruker jeg brunfargen og viser hvordan tankene faller sammen og visner. Samtidig benytter jeg anledningen til å si at ingen med tankesykdommer kan få hjelp av barn. De må få hjelp av doktor eller psykolog som har gått på mange skoler og lært om tankesykdommer. H vis den som făr tankesykdommer har barn, er tankene på dem de aller siste som visner. Da kan det hende jeg tegner to sterke, grønne streker blant alle de brune som har falt sammen. Jeg skriver barnas navn på de to gjenlevende, friske og grønne tankene. Jeg bruker også svartfargen og tegner mørke rundt alle tankene som har visnet og falt sammen. M en så blir også de aller siste tankene syke. De tenker: "Jeg klarer jo ikke å ta vare på meg selv, hvordan skal jeg da klare å være mor/far for mine barn?" N å blir det helt mørkt der inne. 


\section{R eisen til døden}

D a er det bare en eneste tanke igjen, og den er syk. Det er en svart tanke inne i mørket, og den sier: "Jeg må dø. Jeg må reise til døden. Det er det eneste sted for meg nå." O g for å dø må en slutte å puste, og for å slutte å puste må en ta et tau rundt halsen og det heter å henge seg. Eller for å slutte å puste må jeg fylle lungene med vann. Det heter å drukne seg. Eller for å dø må jeg tappe ut alt blodet. Det kan gjøres ved å skjære over pulsårene eller stikke kniv i hjertet. For å dø må en stanse hjerteslagene, og det kan gjøres med veldig sterke medisiner. Eller for å dø må en ta bort alle tankene. Det kan gjøres ved å skyte skudd inn i hodet.

Jeg råder selvsagt ikke foreldrene til å liste opp all verdens selvmordsmåter. Jeg bruker bare den som er aktuell i det enkelte tilfellet. $0 \mathrm{~m}$ jeg råder foreldre i en familie hvor en har hengt seg eller tatt overdose, kan jeg likevel fortelle hva jeg har sagt til barn som har mistet noen som har skutt seg eller drept seg selv med kniv. Slik at de forstår prinsippet. Ikke sjelden synes de at det de skal snakke med barna om, er litt "lettere". O fte er de i full gang med selv å utforme ordbruken når de skal fortelle sine barn om det forferdelige som har hendt dem. Forklaringen om tankesykdommer er den mest alminnelige, fordi den kan anvendes på depresjon, mørke og kulde som gjør at tankene visner, psykose og rus/overdose som gjør at tankene ikke kan styres fordi alt roter seg til. N år det gjelder voldsomme sel vmord som skyting, smadring i bil, hopping fra bru, fjell, ut i foss, fra 15. etasje, snakker jeg noen ganger om sinne og sinte tanker. Tankene blir så sinte og triste samtidig, de tenker at de skal hevne seg, og så vender sinnet seg innover og personen blir sint på seg selv og vil derfor drepe seg selv.

\section{Er alle tankene syke?}

$\mathrm{N}$ oen barn kjenner umiddelbart igjen signaler på tankesykdommer, som de oppfattet mens den nå døde person begynte å bli syk. A ndre barn kan si: "M en jeg merket ingenting. $\mathrm{H}$ an var akkurat som $\mathrm{f} ø \mathrm{r}$. Den siste kvelden kom han inn til meg og ga meg en ekstra klem." Da kan jeg snakke om at de daglige tankene, de som gjør at vi vasker oss, kler på oss, spiser og snakker med andre, var ganske friske. De tankene som var blitt syke, var de lenger inne. Tankene om meg selv. For noe større barn kan jeg også snakke om at tankene kan visne, og man kan få depresjon fordi hjernen får for lite av noen spesielle "vitaminer" som heter serotonin. D et krever imidlertid en del planlegging for valg av tidspunkt og ordbruk. Slik at barna ikke havner i en endeløs grubling og tristhet over at den døde ikke fikk slike medisiner.

\section{$D$ et finnes ingen oppskrift}

Det finnes ingen universaloppskrift. Derfor har jeg heller ikke forsøkt å få det jeg har skrevet her, til å ligne en standardmal. Jeg har villet dele eksempler på forklaringsmåter som jeg selv enten har brukt overfor små barn, eller som jeg har anvendt for å hjel pe foreldrene til å komme videre. Det er mulig å fortelle små barn sannheten på en for dem forståelig måte. I seg selv bedrer ikke det på den faktiske situasjonen. Det som har hendt har hendt, og den som er dø kan aldri komme tilbake. M en slike samtaler som jeg her har gitt eksempler på, hjelper barnet til å sørge og til å dele sorgen med andre, fordi de nå er på samme sted som resten av familien.

\section{En spesiell metode}

M en hva med fireåringer? For dem har jeg ofte anvendt en spesiell metode jeg har utviklet i samarbeid med familier med barn som velger å være åpne og snakke om forferdelig hendelser; i stedet for å gjøre dem til forferdelige hemmeligheter. I tillegg til ved selvmord har jeg gitt råd til familier med små barn hvor pappa, eller andre nære familiemedlemmer, sitter i fengsel etter drap, voldtekt, incest, mordbrann eller narkotikaforbrytel ser, for å nevne noen av de verste og mest "alminnelige" katastrofene en familie med små barn kan bli nødt til å forholde seg til.

I slike situasjoner har jeg hjulpet de fungeren de voksne til å skrive en liten "bok" beregnet på barn i alderen sju til åtte år. H er har de med enkle ord skrevet ned fakta og forklaringer på det som har hendt, inkludert rettssak, nyhetsoppslag og fengsling. I tillegg har vi trenet på det de skal si til fireåringen her og nå. Deretter har de latt barnet få se og bla i den lille boken og fått vite at alt er skrevet opp her. Denne boken skal de voksne lese fra og forklare etter hvert som barnet blir større. H er står alt som har hendt. Det er imidlertid viktig at den første versjonen inneholder alle hovedelementene, og at historien ikke blir verre og verre etter hvert, med stadig nye og skremmende opplysninger. En forklaring til en fireårig sønn av en drapsdømt far, et barn som fortsatt har jevnlig kontakt med farmor, kan begynne slik: "Pappa er i fengsel.

Der har han stol, seng, bord og noen av tingene sine. I et fengsel er man låst inne på et rom. De som passer på i fengselet, er ikke slemme. De kommer med mat tre ganger om dagen, og en gang om dagen får pappa gå ut i fengsel sgården. Der er det høye murer, slik at ingen kan komme ut. Der ute kan han være sammen med andre. Pappa er i fengsel fordi han gjorde noe vel dig galt." Deretter kommer historien om de tankesykdommene som pappa fikk fordi han tok noen sprøyter som gjorde tankene veldig farlige. Så kommer knivstikkingen, om alt blodet som rant ut, slik at personen døde. Det er mange elementer som jeg ikke går inn på her, i og med at de må tilpasses det enkelte barn og den enkelte situasjon. I denne situasjonen ga jeg råd til mor og farmor samtidig, og ga også det råd at de sammen skulle snakke med gutten. De skulle ikke snakke lenge ad gangen, de skulle gi rom for spørsmål og reaksjoner, og de skulle tegne og forklare. De skulle fortelle om boken de har

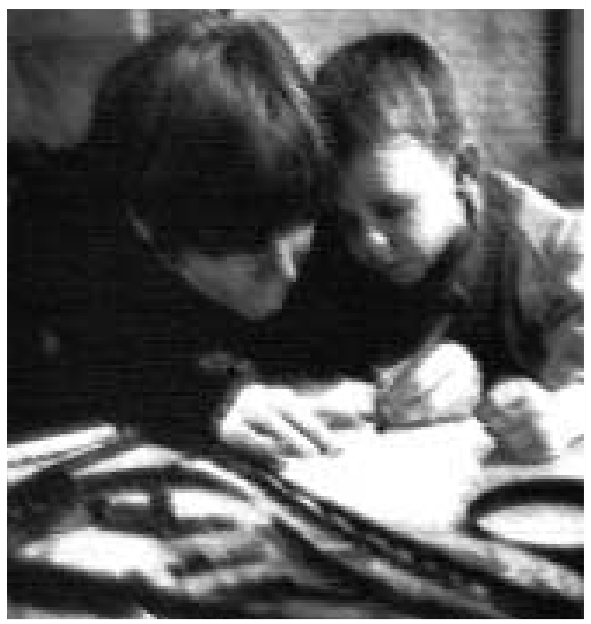

foran seg, og de skulle også si til barnet at dette skulle de snakke om flere ganger. J eg gir også det rådet at de sier til barnet at dette er så vanskelig at det bare skal snakke med voksne om det. $0 \mathrm{~g}$ bare de voksne som vet det. De som vet det, er 
mamma, mormor, morfar, farmor og tante Else. En mor hadde klippet ut bildene av dem som de kunne snakke med fordi de visste det, og limte dem inn i den lille boken.

\section{H va skal vi si om homofili?}

M en hva med homofili som årsak til selvmord? På foreldremøtet i barnehagen hvor den homofile førskolelæreren hadde tatt sitt eget liv, tok styreren dette opp med foreldrene. De var innstilt påå snakke med barna om selvmord og årsaker til selvmord - det vil si depresjon. Stemningen blant dem var negativ når det kom til spørsmålet om de skulle snakke med barne om homofili, som førskoleIæreren selv hadde skrevet om i avskjedsbrevet. Foreldrene var likevel meget interessert i å snakke om hvordan dette eventuelt kunne gjøres. Styreren tok utgangspunkt $i$ at han hadde fătt en tankesykdom som het depresion. Deretter ful gte forklaringen med tankene som visnet og at alt ble mørkt, og til slutt tenkte han bare på reisen til døden. For å dø val gte han å stoppe å puste. For å stoppe pusten bestemte han seg for å henge seg. $\mathrm{H}$ an fikk disse tankesykdommene fordi han ble så trist når alle syntes han var dum, fordi han ville ha en mann til kjæreste i stedet for en dame - slik som alle de andre mennene hadde. To foreldrepar hadde bedt om samtale med styreren for å gå igjennom dette en gang til etterat det var gått en stund. G runnen var at guttene deres hadde begynt å snakke om at "han hengte seg fordi han var homo".

En av fedrene som hadde snakket med sin sønn, hadde gitt tilbakemelding om at det hadde gått mye bedre enn han trodde. G utten hadde lyttet interessert, spurt innimellom, og til slutt sett på far og sagt. "Jeg vil ikke henge meg hvis jeg făr en gutt til kjæreste fordi du ikke synes det er dumt." Far hadde da sagt at han trodde gutten kom til å finne seg en dame og bli kjæreste med henne slik som pappa hadde blitt glad i mamma, men om han ville bo sammen med en mann, ville ikke pappa si at han var dum. H vorpå gutten hadde hoppet ned av fanget og sagt: "Da trenger vi ikke å snakke mer om det." Det trengte de sikkert, men ikke der og da.

\section{Oppsummering}

Vi kan ikke holde barna utenfor den nye åpenheten om selvmord. $N$ år vi forteller dem om det tragiske faktum at noen ikke klarer å "bære det tunge livet", men avslutter det selv, kommer vi ikke utenom årsakene. $\mathrm{H}$ vis vi bare beretter om det forferdelige uten å formidle en forståelig forståelse, risikerer vi at åpenheten påfører barnet ekstra angst og spenning. Jeg sier ikke med dette at det er bedre med taushet dersom vi ikke synes vi kan si noe om årsaken til selvmordet. Det jeg sier er at vi må bestrebe oss på å formidle vår egen forståelse, den være seg både stykkevis og delt, på en slik måte at den kan begripes av barn; endog av små barn. $H$ ar vi lagt et grunnlag som er så forståelig og sannferdig som mulig umiddel bart etter at selvmordet fant sted, har vi noe å bygge videre på når barna vil vite mer fordi de er blitt eldre og kan forstå mer.

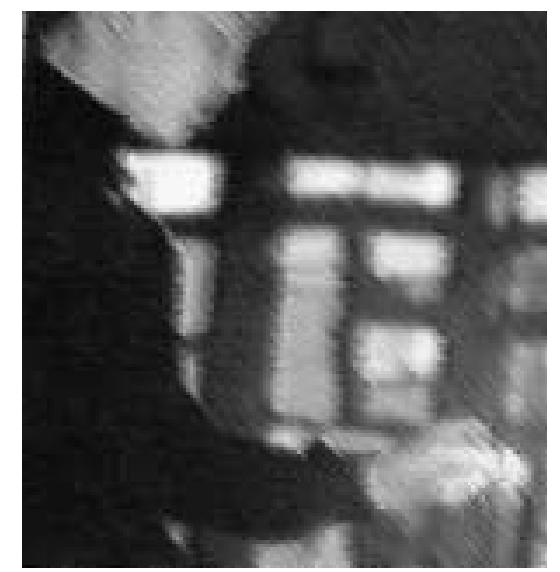

Det finnes ingen oppskrift, men praktisert åpenhet har etter hvert gitt oss mange erfaringer og eksempler som vi trenger å dele med hverandre. G jennom dette vil vi bli bedre forberedt til å møte de vanskeligste spørsmål ene barna trenger voksenhjelp til å få svar på.

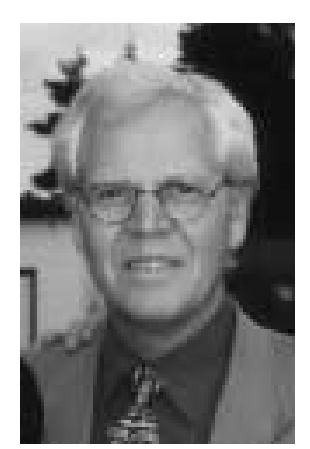

$M$ agne Raundalen er psykolog. Han var amanuensis ved Univ. i Bergen 197590, og har siden da vært tilknyttet Senter for K risepsykologi i Bergen. $\mathrm{H}$ an ledet prosjektet "O msorg for familier til barn med kreft"1980-83 og har arbeidet med krigstraumatiserte barn hjemme og ute siden 1984. 